\title{
Exploitation Of Aquatic Fauna During The Metal Age In Bukit Kamiri, Semporna, Sabah, Malaysia
}

\author{
Velat Bujeng \\ Centre for Global Archaeological Research, USM, Penang \\ Deejay Daxter A. Albert \\ Centre for Global Archaeological Research, USM, Penang
}

\begin{abstract}
This article discussed on the analysis of faunal remains from the aquatic environment uncovered from Bukit Kamiri, Semporna, Sabah, Malaysia. Based on the result of archeozoological analysis, the reptile, fish and mollusc remains from the Metal Age cultural layer were consisted of various fish and molluscs species of freshwater, estuarine, mangrove swamp, coastal, coral reef and marine habitats. A range of fishing, hunting and gathering methods were used to obtain the various types of food and resources. Besides their diet, the reptile, fish and mollusc remains also show that it was used multi-purposely as grave goods, based on its association with the finding of human burial.
\end{abstract}

Keywords: archaeology, Bukit Kamiri, aquatic faunal remains, grave goods.

\section{INTRODUCTION}

An excavation had been carried out in 2007 by the Centre for Global Archaeological Research (CGAR), Universiti Sains Malaysia (USM), Penang, Malaysia in collaboration with the Sabah Museum Department and the National Heritage Department at the volcanic rock shelter site of Bukit Kamiri, Semporna, Sabah, Malaysia (Figure 1). The excavation had shown evidences of a Late Prehistoric (Metal Age) culture dated 2,830 BP (Chia et al., 2005:204; Chia, 2007; 2008; 2016; Eng, 2009:175-176; Eng and Chia, 2010:44). The material cultures found were stone tools, pottery shards, beads, metal objects, human skeletons and faunal remains (vertebrate and invertebrate remains). The faunal remains from the Metal Age layer had been analysed by using archaeozoological approaches. However, the discussion that will be focused in this paper is only on the result of the analysis on aquatic fauna which are reptilian bones, fish bones and mollusc remains.

\section{METHOD OF THE STUDY AQUATIC FAUNAL REMAINS}

The methods that are applied in analysing the samples are anatomic, taxonomic and statistical analyses. The aim of anatomic analysis is to identify the anatomic parts or terminologies of vertebrates and invertebrates (Hesse and Wapnish, 1985; Claassen, 1998; Yule and Yong, 2004; Matsui, 2007). This analysis could also help in obtaining potential samples for the taxonomic identification done in the taxonomic analysis (Reitz and Wing, 1999; Pickering et outcome of this analysis will be quantified into statistical data, especially in calculating the minimum number of individuals (MNI) (Renfrew and Bahn, 1996; Harris et al., 2015). These data could give an indicator on the daily activities of the prehistoric societies especially in food processing (Pickering and Egeland, 2006; Faith et al., 2009). Taxonomic analysis is a method used to identify the types of fauna according to the taxonomic hierarchy such as Class, Order, Suborder, Family, Genus and Species (Hesse and Wapnish, 1985; Reitz and Wing, 1999; Allen, 2000). The identification is done by referring to reference specimens as well as various 
reference books such as Saunders (1979), Dance (1992), Poutiers (1998a and 1998b), Reitz and Wing (1999), Allen (2000), Abbott, (2002), Fiene-Severn et al. (2004), Das (2006), Matsui (2007), Yule and Yong (2004), Hook (2008) and Azmi et al. (2010). Thus, the species of aquatic fauna exploited by the Metal Age societies in Semporna can be determined. Taxonomic data would also contributes to strengthen the interpretation on their adaptation and environment (Bekken et al., 2004:333; Grabarkiewz and Davis, 2008:5; Cranbrook, 2010:374). Meanwhile, the statistical analysis approaches that are applied in this discusson are the number of identified specimens (NISP), MNI and weight. The analysis of NISP refers to the number of specimens (parts of skeletons and shells) that can be identified according to its taxonomy while the analysis of MNI determine the number of animals that are exploited based on the statistics of NISP (Klein dan Cruz-Uribe, 1984:25; Reitz and Wing, 1999:192; Renfew dan Bahn, 1996:273; Grant et al., 2008:73; Giovas, 2009; Harris et al., 2015).

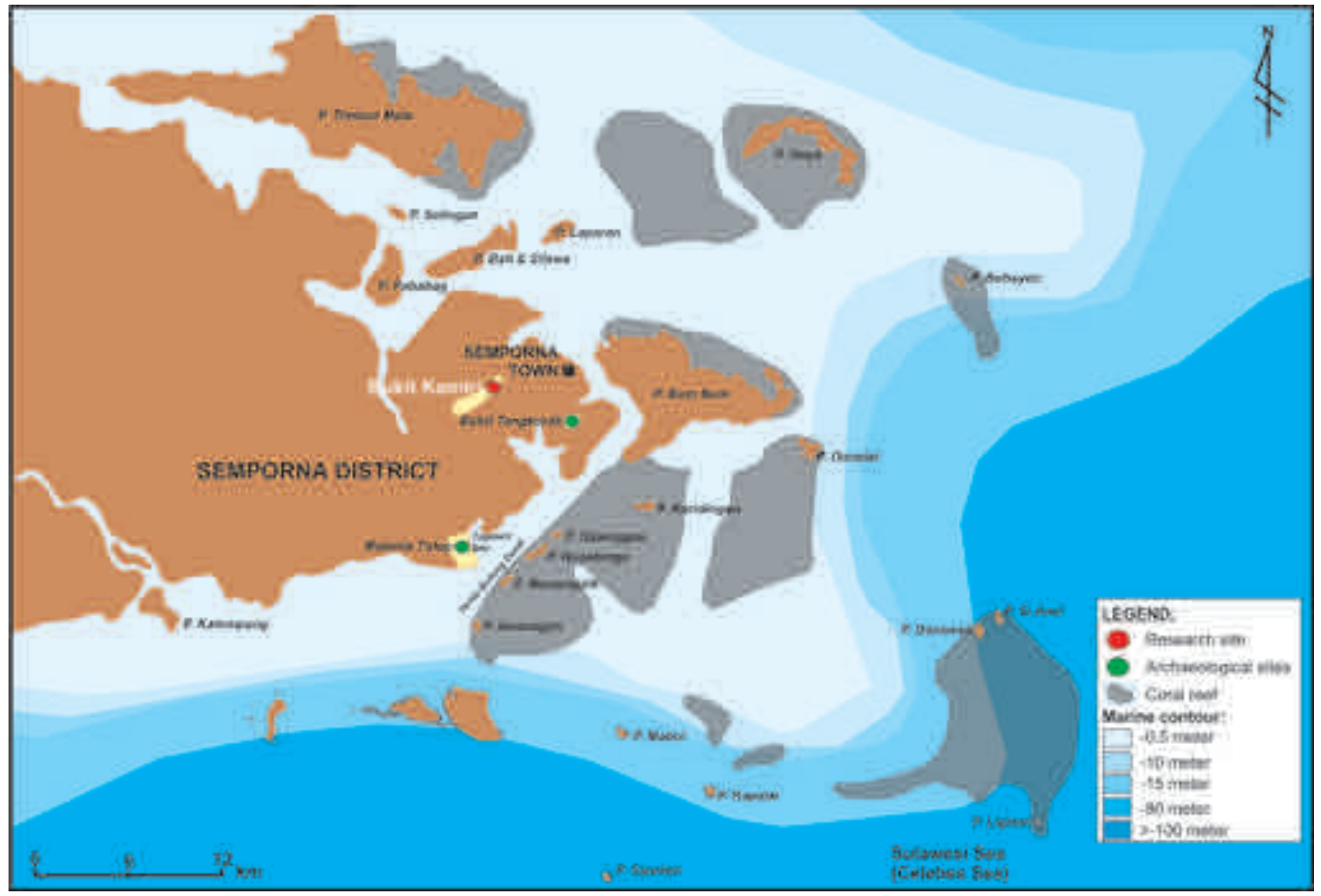

Figure 1: The location of Bukit Kamiri site at Semporna, Sabah, Malaysia. (Adapted from: LEMBAR (Sheet) 4/118/11)

\section{RESULTS OF AQUATIC FAUNAL REMAINS ANALYSIS}

The total of specimens analysed are 517 samples or $711.4 \mathrm{~g}$ in weight (Figure 2). Based on anatomic and taxonomic analysis, the vertebrate aquatic faunal remains sample (189 NISP/348.5 g) can be divided into two main classes which are reptiles (26 NISP/161.2 g) and fishes (163 NISP/187.3 g) while the invertebrate aquatic faunal remains sample (230 NISP/331.6 g) can be divided into two main classes which are gastropods (128 NISP/124.1 g) and bivalves (102 NISP/207.5 g). Discussions on the identified aquatic faunal remains according to the vertebrate and invertebrate classes are as follows. 


\section{Reptililian Bones}

The aquatic reptile that has been identified is from the Cheloniidae family or turtles. The anatomy of turtle specimens that are identified are the pectoral girdle and carapace (pleural). The species of turtles that were exploited by the Metal Age societies in Bukit Kamiri are most likely Chelonia mydas, Eretmochelys imbricata or Lepidochelys olivacea. All of these three species of turtles are still recorded to exist in the Malaysian coast (Leong and Siow, 1984:192; Das, 2006:131-133). Previous studies of faunal remains at other sites in Semporna such as Bukit Tengkorak and Melanta Tutup also found evidence of the exploitation of turtles during the Metal and Neolithic Age (Chia, 2003; 2016; Velat and Chia, 2014). However, there are no specimens suitable to calculate for MNI.

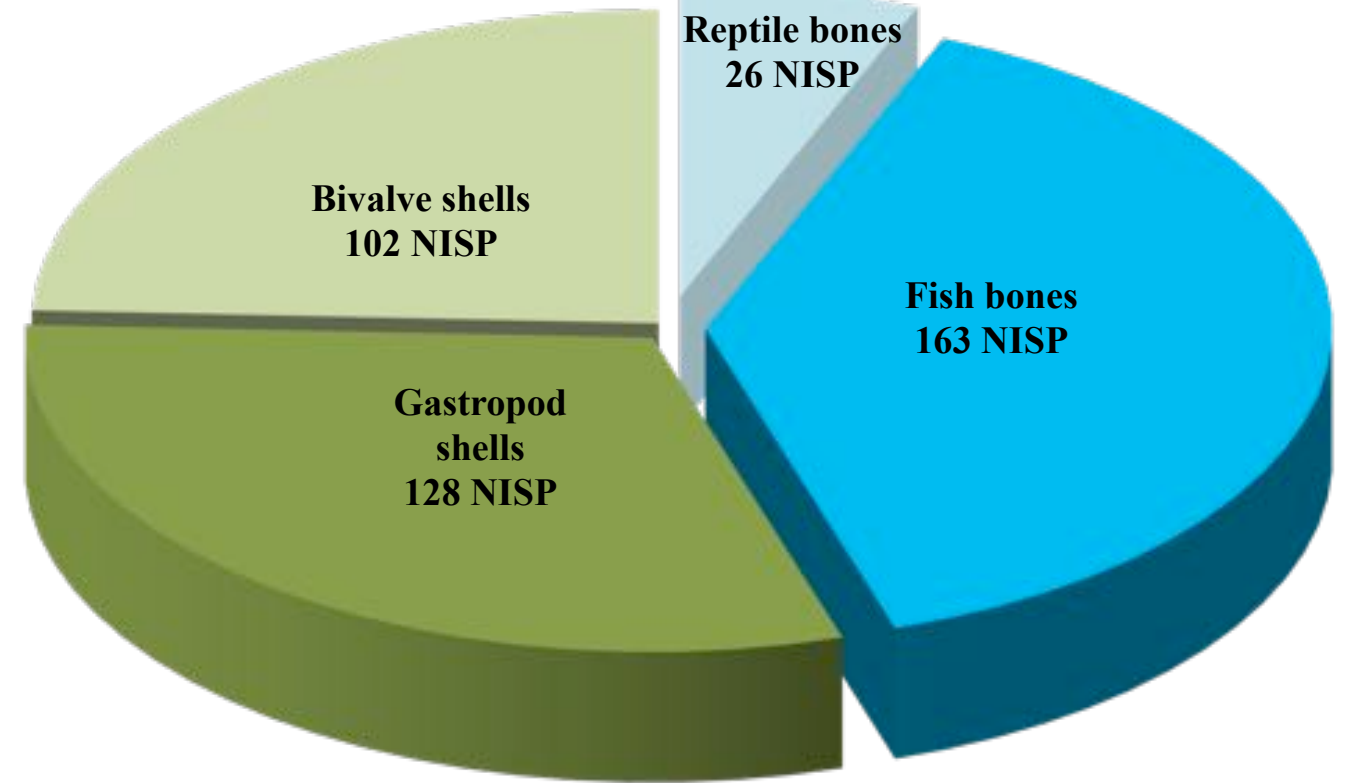

Figure 2: The aquatic faunal remains represented by NISP in Bukit Kamiri, Semporna

\section{Fish Bones}

Based on the morphological characteristics of the fish bones identified from Bukit Kamiri, the exploited fish could be divided into either Osteichthyes or Condrichthyes class. The total number of Osteichthyes specimens found in Bukit Kamiri is 163 NISP (187.3 g) and 20.9 percent of them can be identified according to various familiae such as Diodontidae, Tetraodontidae, Serranidae, Scaridae, Sparidae, Scombridae and Lethrinidae. Meanwhile, the rest of them are specimens that could not be identified to their familiae and classified under the Osteichthyes class only. The identification is hard to be done as the specimens are consisted of small fragments. Meanwhile, the identification of fish from the class Condrichthyes to their familiae are also hard and could only be speculated that they are from the order Archarhiniformes. The result of the analysis and statistics according to the fish familiae is as follows.

Diodontidae: The fish from this family is known as the porcupinefish. The anatomy of the porcupinefish specimens that has been identified are the dentary parts. The species of porcupinefish that were exploited by the Metal Age societies of Bukit Kamiri were possibly Diodon liturosus or Diodon hystrix. Both of these species are categorised as highly-toxic fish and could be fatal if eaten (Allen, 2000; Lieske and Myers, 1994). However, these species of porcupinefish has been one of the local delicacies among the Bajau Laut in Sabah even today (Ridzwan, 1993:222). Based on NISP, two dentaries found means that there are a minimum of 
two porcupinefish exploited. This is because each porcupinefish only has a single dentary (Table 1).

Table 1: Statistics on NISP and MNI of porcupinefish and pufferfish from Bukit Kamiri, Semporna

\begin{tabular}{c|cc|c}
\hline Family/Anatomy & NISP & MNI & Weight (g) \\
\hline \hline Diodontidae Dentary & 2 & 2 & \\
\hline Sub-total & 2 & 2 & 8.6 \\
\hline Tetraodontidae & & & \\
Dentary & 2 & 1 & 60.7 \\
\hline Sub-total & 2 & 1 & 60.7 \\
\hline Total & $\mathbf{4}$ & $\mathbf{6 9 . 3}$ \\
\hline \hline
\end{tabular}

Tetraodontidae: The identification of the fish from the Tetraodontidae family is also based on its dentary. The species of fish from the Tetraodontidae family is pufferfish that is related with the fish from the Diodontidae family (Matsui, 2007:93). Based on the statistics, only one MNI of this family can be determined (Table 1). This is due to the fact that a pufferfish can only have a pair of dentary.

Serranidae: There are various species and sizes of fish under this family which are mainly living around coral reef and estuarine (Allen, 2000:82-90). Grouper fish is one of the fish under this family. Based on the specimens that are identified, it is most likely that the species of grouper fish exploited in Bukit Kamiri is Epinephelus malabaricus or the Malabar grouper. A total of 12 spesimens or $5.1 \mathrm{~g}$ in weight of grouper fish are identified (Table 2). Among the identified specimens are dentary (1 NISP/0.4 g), premaxilla (5 NISP/2.5 g) and maxilla (6 NISP/2.2 g). Based on the NISP statistics, the MNI of grouper fish exploited is five (Table 2).

Table 2: Statistics on NISP and MNI of Serranidae fish from Bukit Kamiri, Semporna

\begin{tabular}{r|cc|c}
\hline Anatomy & NISP & MNI & Weight (g) \\
\hline \hline Dentary & 1 & - & 0.4 \\
Premaxilla & 5 & 2 & 2.5 \\
Maxilla & 6 & 3 & 2.2 \\
\hline Total & $\mathbf{1 2}$ & $\mathbf{5}$ & $\mathbf{5 . 1}$ \\
\hline \hline
\end{tabular}

Scaridae: The fish under the Scaridae family is parrotfish and mostly from the coral reef ecology. Based on the different characteristics on the pharyngeal and premaxilla, there are two species of parrotfish identified which are Bolbometopon muricatum (double-headed parrotfish) and Bolbometopon bicolor (bicolour parrotfish). There are ten specimens (22.0 g) of Bolbometopon muricatum and five specimens (30.5 g) of Bolbometopon bicolor that are identified (Table 3). Based on the pharyngeal and premaxilla parts, the total of Bolbometopon muricatum is four MNI and Bolbometopon bicolor two MNI (Table 3). 


\section{Table 3: Statistics on NISP and MNI of Scaridae fish from Bukit Kamiri, Semporna}

\begin{tabular}{c|cc|c} 
Famliy/Anatomy & NISP & MNI & $\begin{array}{c}\text { Weight } \\
\text { (g) }\end{array}$ \\
\hline \hline $\begin{array}{c}\text { Bolbometopon muricatum } \\
\text { Pharygeal }\end{array}$ & 3 & 1 & 3.3 \\
Premaxilla & 7 & 3 & 18.7 \\
\hline $\begin{array}{c}\text { Bolbometopon bicolor } \\
\text { Premaxilla }\end{array}$ & 5 & 4 & 22 \\
\hline Sub-total & 5 & 2 & 30.5 \\
\hline Total & $\mathbf{1 5}$ & $\mathbf{6}$ & $\mathbf{5 2 . 5}$ \\
\hline \hline
\end{tabular}

Sparidae: The fish specimen from the Sparidae family is under the group of breams fish. Based on the premaxilla (1 NISP/4.2 g) that has been identified, the species is probably Sparus sarba or also known as Goldlined sea bream. However, the MNI cannot be determined due to lack of enough specimens.

Scombridae: Tuna fish is one of the species in the Scombridae family. The identification is based on the premaxilla part (1 NISP/1.1 g). Due to lack of specimens, the MNI for tuna fish also cannot be determined.

Lethrinidae: Based on identified specimens, the fish from the Lethrinidae family is probably Lethrinus laticaudis (Grass emperor). However, since there is only one NISP of this species found which is the premaxilla part, the value of MNI cannot be determined.

Condrichthyes: The total number of specimens identified under the class Condrichthyes is 16 NISP and $10.9 \mathrm{~g}$ in weight. The identified specimens are three vertebrae bones that are believed to be shark fish from the order Archarhiniformes.

\section{Mollusc Remains}

The mollusc remains that are analysed are divided into two main class, which are Bivalvia (102 NISP/207.5 g) and Gastropoda (128 NISP/124.1 g) (Figure 2). There are four familiae of Bivalvia that have been identified, which are Arcidae, Cyrenidae, Lucinidae dan Ostreidae (Table 4). Meanwhile, for Gastropoda, there are eight familiae that are identified, which are Thiaridae, Stromidae, Pachychilidae, Potamididae, Muricidae, Neritidae, Conidae and Turbinidae (Table 4). 
Table 4: Statistics on NISP and MNI of mollusc remains from Bukit Kamiri, Semporna

\begin{tabular}{|c|c|c|c|}
\hline Family & NISP & MNI & Weight (g) \\
\hline \multicolumn{4}{|l|}{ Bivalvia } \\
\hline Arcidae & 49 & 7 & 113.6 \\
\hline Cyrenidae & 46 & 3 & 54.9 \\
\hline Lucinidae & 5 & 0 & 7.2 \\
\hline Ostreidae & 2 & 0 & 31.8 \\
\hline Sub-total & 102 & 10 & 207.5 \\
\hline \multicolumn{4}{|l|}{ Gastropoda } \\
\hline Thiaridae & 24 & 15 & 16.2 \\
\hline Strombidae & 35 & 12 & 51.2 \\
\hline Pachychilidae & 16 & 11 & 11.8 \\
\hline Potamididae & 32 & 8 & 20.3 \\
\hline Muricidae & 14 & 3 & 18.6 \\
\hline Neritidae & 3 & 2 & 1.6 \\
\hline Conidae & 1 & 0 & 1.8 \\
\hline Turbinidae & 3 & 0 & 2.6 \\
\hline Sub-total & 128 & 51 & 124.1 \\
\hline Total & 230 & 61 & 331.6 \\
\hline
\end{tabular}

Arcidae: There are two species of Arcidae or ark clams that are identified, which are Anadara antiquata and Tegillarca granosa. Anadara antiquata lives on muddy bottoms in the littoral and sublittoral zone of the sea, while Tegillarca granosa lives on muddy bottoms in the littoral and shallow sublittoral zone of the estuarine or in mangrove swamps (Poutiers, 1998a). Both of these species are native in the Indo-Pacific region and are locally collected for food not only in Malaysia but in Indonesia, Thailand and Australia (Meehan, 1982; Ridzwan, 1993; Poutiers, 1998a). This family represents the most dominant bivalves found in the Metal Age layer of Bukit Kamiri. Although it is the most in terms of weight, but due to fragmentation a lot of specimens cannot be used to calculate for MNI.

Cyrenidae: The shells of the Cyerinidae family can be distinguished with other clams based on their thick hinges with strong lateral teeth and three diverging cardinal teeth in each valves (Poutiers, 1998a). Malaysians called them as lokan and they are widely collected as food (Ridzwan, 1993; Poutiers, 1998a). They live in soft bottoms of shallow fresh or brackish water areas such as in mangrove swamps (Poutiers, 1998a). Specimens can only be confidently identified to its genus level, Geloina sp. as they are mostly fragmented. They could only be identified based on the distinguishable features of their teeth and hinges.

Lucinidae: The specimens of the Lucinidae family found in the Metal Age layer of Bukit Kamiri are mostly fragmented but identifiable based on their deep concentric growth lines that could resembles either the Anodontia or Austriella genus. However, there are no distinct anatomical parts present on specimens that could be calculated for MNI. Both Anodontia sp. and Austriella sp. lives in the mangrove swamp areas and are locally marketed in central Philippines for food, shell-craft and lime-making (Poutiers, 1998a).

Ostreidae: The Ostreidae family or oysters lives cemented to hard substrates mainly in littoral and shallow sublittoral zone of the sea (Poutiers, 1998a). The specimens are identified based 
on their irregular shape. However, the species and the MNI of the Osteridae specimens cannot be determined because the specimens are fragmented and abraded.

Thiaridae: Balanocochlis glandiformis belongs to the Thiaridae family and it is the most abundant mollusc in the Metal Age layer of Bukit Kamiri according to its MNI. This species lives in rivers with sandy bottom in the forests and occurs mainly in Borneo (Galli, 2016; Poppe and Poppe, 2017). However, Pyron and Brown (2015:389) stated that this species is at risk of extinction. Based on the photos by Poppe and Poppe (2017) and Femorale (2017), specimens are identifiable as Balanocochlis glandiformis based on the similarity of their anatomy, such as the spire, aperture and shape of outer lips.

Strombidae: Molluscs from the Strombidae family or conchs are mainly living in shallow water on sandy, muddy or rubble bottoms or on marine grassflats as well as coral reef (Poutiers, 1998b). Due to fragmentation, specimens from this family can only be identified to their genus, Strombus. However, it can be said that there are perhaps more than one species of Strombus among the specimens, probably Strombus urceus, Strombus labiatus or Strombus canarium. Nevertheless, these Strombus spp. are edible and locally collected for food as well as shell-crafts (Ridzwan, 1993; Poutiers, 1998b).

Pachychilidae: Brotia sp. is the third most dominant gastropod remains found in the Metal Age layer of Bukit Kamiri according to its MNI. The genus Brotia from the Pachychilidae family are mainly consisted of freshwater snails that are conical to broadly elongated with a turreted spire and a well-rounded to angulate and broad aperture (Koehler and Glaubrecht, 2002). These features are all found present in the specimens found. However, fragmentation and abrasion of specimens make it hard to identify samples no lower than its genus level. Most of the specimens are found to have missing apices, probably cut or smashed during food preparation.

Potamididae: There are two species of Potamididae that are found which are Terebralia sulcata and Telescopium telescopium. Both of these species live on mud flats in the littoral zone of estuarine and mangrove swamp areas (Poutiers, 1998b). They are also still locally collected as food not just by the people in Sabah but also in Peninsular Malaysia, Thailand, Indonesia and Philippines (Wong et al., 1984; Ridzwan, 1993; Poutiers, 1998b; Nilus et al., 2010).

Muricidae: The shells of the murex shells or Muricidae usually have spines, tubercles or bladelike processes. The species of this family is most likely Hexaplex cichoreum based on anatomic analysis. This species lives in rocky to muddy areas in low tide of the littoral zone and in the sublittoral zone and also still collected for food and shell-crafts (Poutiers, 1998b).

Neritidae: The shells of Neritidae family or nerites have a very distinguished anatomic feature where the aperture is semicircular (Fiene-Severns et al., 2004). Nerites that are found in the site are believed to be from the genus Nerita based on anatomic analysis. Nerita sp. usually lives in rocky shores in the littoral zone as well as in the shallow coral reef areas (Poutiers, 1998b). Nerita sp. is called sesuk in the Bajau Laut language and prized for food as well as shellcrafts (Ridzwan, 1993; Poutiers, 1998b).

Conidae: Molluscs of the Conidae family or cone shells have cone-shaped shells with a low spire and a long aperture (Poutiers, 1998b). Although some cone shells are venomous, some are known to be locally used as food in the Indo-West Pacific (Poutiers, 1998b). In addition, cone shells are favourites among shell collectors and are traditionally modified as ornaments 
in Sabah as well as across the Indo Pacific region (Ridzwan, 1993; Poutiers, 1998b). Cone shells are mainly living under rocks or corals in the littoral and shallow sublittoral zones.

Turbinidae: Molluscs from this family are mainly living in the rocky bottoms or shallow coral reef in the littoral and shallow sublittoral zones (Poutiers, 1998b; Abbott, 2002). They are also edible and used for shell-crafts (Ridzwan, 1993; Poutiers, 1998b). Specimens of Turbo sp. found in the site are identified based on its outer sculpture that is nodular, resembling either Turbo setosus or Turbo bruneus. But, there are no distinguished anatomical parts present to calculate for MNI.

\section{DISCUSSION AND CONCLUSION}

During the Metal Age (2,830 BP) at Bukit Kamiri, Semporna, the exploitation and adaptation patterns of its societies were consisted of various types of food resources ranging from the river, estuarine, mangrove swamp, coastal, coral reef and marine environment. This is evident based on the exploitation of aquatic fauna such as turtles, fish and molluscs. These subsistence and adaptation activities were also influenced by the environment during that time. For example, fishes from the coral reef environment ranging from the littoral to the sublittoral zones as deep as $60 \mathrm{~m}$ were exploited as the source of diet, such as the porcupinefish, parrotfish, breams fish, grouper fish and emperor fish. Besides that, molluscs that are gathered are also from the same environment as these fishes, such as Hexaplex cichoreum, Conus sp., Turbo sp. and Anadara antiquata (Table 5). Fishing activities also took place in the lagoon environment based on the findings of shark fish specimen. They also exploited various species of diet resource from the estuarine and mangrove swamp environment, such as the pufferfish and molluscs (Tegillarca granosa, Geloina sp. and Terebralia sulcata; Table 5). The findings of Balanocochlis glandiformis and Brotia sp. also show that mollusc gathering took place at freshwater rivers in the surroundings of open forest. 


\begin{tabular}{|c|c|c|c|}
\hline Class & Family & Genus species & Habitat \\
\hline \multirow[t]{9}{*}{ Gastropoda } & Muricidae & Hexaplex cichoreum & $\begin{array}{l}\text { Marine (rocky to muddy } \\
\text { bottoms in low tide and } \\
\text { sublittoral zone) }\end{array}$ \\
\hline & Conidae & Conus sp. & $\begin{array}{l}\text { Marine (rocky or coral } \\
\text { reef in littoral and } \\
\text { shallow sublittoral zone) }\end{array}$ \\
\hline & Turbinidae & Turbo sp. & $\begin{array}{l}\text { Marine (rocky or coral } \\
\text { reef in littoral and } \\
\text { shallow sublittoral zone) }\end{array}$ \\
\hline & Strombidae & Strombus spp. & $\begin{array}{l}\text { Marine (sandy, rocky or } \\
\text { coral reef in littoral zone) }\end{array}$ \\
\hline & Neritidae & Nerita sp. & $\begin{array}{l}\text { Marine (rocks or coral } \\
\text { reef in littoral zone) }\end{array}$ \\
\hline & Potamididae & Terebralia sulcata & $\begin{array}{l}\text { Mangrove swamp / } \\
\text { Estuarine (littoral zone) }\end{array}$ \\
\hline & Potamididae & Telescopium telescopium & $\begin{array}{l}\text { Mangrove swamp / } \\
\text { Estuarine (littoral zone) }\end{array}$ \\
\hline & Thiaridae & $\begin{array}{l}\text { Balanocochlis } \\
\text { glandiformis }\end{array}$ & Freshwater \\
\hline & Pachychilidae & Brotia sp. & Freshwater \\
\hline \multirow[t]{5}{*}{ Bivalvia } & Arcidae & Anadara antiquata & $\begin{array}{l}\text { Marine (muddy bottoms } \\
\text { in littoral and sublittoral } \\
\text { zone) }\end{array}$ \\
\hline & Arcidae & Tegillarca granosa & $\begin{array}{l}\text { Mangrove swamp } \\
\text { Estuarine (littoral and } \\
\text { shallow sublittoral zone) }\end{array}$ \\
\hline & Lucinidae & sp. & $\begin{array}{l}\text { Mangrove swamp } \\
\text { Estuarine (littoral zone) }\end{array}$ \\
\hline & Cyrenidae & Geloina sp. & $\begin{array}{ll}\text { Mangrove } & \text { swamp } / \\
\text { Freshwater } & \end{array}$ \\
\hline & Ostreidae & sp. & $\begin{array}{l}\text { Marine (attached on hard } \\
\text { substrates in littoral and } \\
\text { shallow sublittoral zone) }\end{array}$ \\
\hline
\end{tabular}

The diversity of species and habitat of aquatic fauna show that there is a variety in the strategies of fishing and gathering practiced by the Metal Age socities. Fishing activities by using nets, spears and poisonous root plants were probably applied especially to catch the Serranidae, Scaridae and Lethrinidae fishes (Chia, 2003:137; Ono, 2003:198; 2004:96). Nets and trawls have been practiced since 5,000 to 2,000 BP especially in the coastal areas in Taiwan and East Timor (Tsang, 1995; O'Connor, 2006). According to Poutiers (1998b), the fishermen in the Philippines traditionally used shells of Strombus canarium as net-sinkers. Thus, evidence of Strombus spp. fragments in Bukit Kamiri could probably indicate their use as net-sinkers. Spearing or harpooning large fish such as sharks are still practiced by the Bajau Laut people in Semporna using what they called as sundak (Ridzwan, 1993:19-20). Besides that, using poisonous plant roots of Derris elliptica might also be practiced although only practical to be used in the shallow coral reef zone (Ono, 2002:96). According to Ono (2003:194), line-fishing technique is the appropriate strategy to apply when fishing for Lethrinidae, Serranidae and Scombridae fishes that are mainly living in shallow littoral coastal areas. The Metal Age societies of Bukit Kamiri also probably had the knowledge and strategy on gathering molluscs according to the tide level, especially in the mangrove swamp and 
estuarine environment. This is because mollusc gathering activities especially in the mangrove swamp (Geloina sp. and Terebralia sulcata) and estuarine (Tegillarca granosa) environment can only be carry out during low tide.

The discovery of porcupinefish had also indicated that the Metal Age societies of Bukit Kamiri were highly knowledgable about the porcupinefish. This is because porcupinefish is categorised among the poisonous fish that are highly toxic and could be fatal if eaten (Ridzwan, 1993; Allen, 2000). Despite that, this fish is safe to eat if it is processed perfectly because the practice of eating porcupinefish is still practiced among the Bajau Laut people in Semporna (Ridzwan, 1993).

Marine turtles (Cheloniidae) are easier to catch when landed to the shore to lay their eggs. Besides that, turtles might be hunted in the coral reef, lagoon or shallow areas either by using spears or nets. However, it is more practicle to hunt turtles when they landed at the beach to lay eggs (Das, 2007:1131-132; Hook, 2008:209). If this method is applied then the Metal Age societies in Bukit Kamiri are very knowledgable in the habit and seasons for the turtles to lay eggs.

Evidence of aquatic faunal remains that have been identified is also associated with the Metal Age burial layer. Hence, it is possible that these specimens were grave goods for the dead. Offerings of food (turtles, fish and molluscs) might have a connection with the belief of life after death. (Medway, 1959/60:372; Zuraina, 1994:39-42). The ritual practiced was unique and had been applied since Late Palaeolithic and Neolithic age in Malaysia (Zuraina, 2005:12-14; Barker, 2005:101; Soejono, 2008:3-5; Goh, 2010:65; Velat and Chia, 2009: 213-124). Indication of burnt bones might also be related with food preparation activities by using fire (Cranbrook, 1988: 148; Pookarjorn, 1994:8; Azman, 1998). Various morphology of fragmentation of mollusc remains may also indicate food preparation. The fleshes of molluscs are easier to obtain depending on the pattern of fragmentation, such as the removal of apices of Brotia sp. and Terebralia sulcata, direct percussion to the body of Telescopium telescopium as well as to the valve of oysters (Meehan, 1982; Zuraina, 1994; Ridzwan, 1993).

As a conclusion, aquatic fauna associated with the evidence of Metal Age human skeletons in Bukit Kamiri are comprised of reptiles, fishes and molluscs. The variety of species of aquatic fauna that are identified clearly show the strategy and technology in hunting, fishing as well as gathering. This is because the habitat of aquatic fauna ranges from the river, estuarine, mangrove swamp, coastal, coral reef (either shallow or deep) and marine environment that are surrounding the site of Bukit Kamiri (Figure 1). Different habitats of aquatic fauna also indicate a high level of exploitation skills that were practiced. Based on the habitats of fish and molluscs, the Metal Age societies in the area most probably used canoes, rafts or boats to travel when hunting, fishing and gathering, especially in coral reef and marine areas. The majority of species of the aquatic faunal remains represented at Bukit Kamiri can still be found in Semporna, suggesting a past environment closely similar to that of the present day Semporna. Hence, the adaptation of the Metal Age societies of Bukit Kamiri is probably the same as today. The concentration of the faunal vertebrate and invertebrate remains that are diverse but lack in quantity suggest that the site does not function as a habitation or seasonal camp. But, the remains of turtles, fish and molluscs are found to be associated with human burial, suggesting that during the Metal Age, Bukit Kamiri site functioned as a burial ground. This further proven that the remains of aquatic fauna are parts of ritual item or grave goods. 


\section{ACKNOWLEDGEMENTS}

First of all, we would like to express our gratitude to Universiti Sains Malaysia, for funding the research through the USM Research Universuty Grant (Kajian Arkeozoologi Zaman Logam di Sabah dan Sarawak: 1001/PARKE0/870012). We owe special thanks to Professor Dr. Stephen Chia Ming Soon for the permission to reanalyse the faunal remains found in the Metal Age cultural layer from Bukit Kamiri, Semporna, Sabah. The authors would like to thank Professor Dato' Dr. Mokhtar Saidin, the Director of the Centre for Global Archaeological Research, USM for the interest and support of this research.

\section{References}

Abbott, R.T., 2002. Seashells of the world. New York: St. Martin's Press.

Allen, G., 2000. Marine Fishes of South-east Asia. Singapore: Periplus Editions (HK) Ltd.

Azman Mohd. Noh, 1998. Ekskavasi Gua Singa and Gua Batu Putih di Grik, Perak. Malaysia Museum Journal, 34 (New Series).

Azmi Ambak, Mansor Mat Isa and Mazlan Abd Ghaffar, 2010. Fishes of Malaysia. Terengganu: Penerbit UMT.

Barker, G., 2005. The archaeology of foraging and farming at Niah, Sarawak. Asian Perspectives, Vol. 44(1), p.91106.

Bekken, D., L.A. Schepartz, A. Miller-Antonio, H. Yamei dan W. Huang, 2004. Taxonomic abundance at Panxian Dadong, A Middle Pleistocene Cave in South China. Asian Perspectives, 43(2), p.333-359.

Chia, S., 2016. Arkeologi Bukit Tengkorak, Sabah. Pulau Pinang: Penerbit Universiti Sains Malaysia.

Chia, S., 2003. The prehistory of Bukit Tengkorak as major pottery making sites in Southeast Asia. Sabah Museum Monograph 8. Kota Kinabalu: Sabah Museum Department.

Chia, S., 2007. The Metal Period in Malaysia. Warisan Arkeologi Malaysia, Series 1, p.109-123.

Chia, S., 2008. Prehistoric sites and research in Semporna, Sabah, Malaysia. Bulletin of the Society for East Asian Archaeology, Vol. 1, p.109-123.

Chia, S., 2010. Pemuliharaan rangka manusia di Malaysia. In: Asyaari Muhamad, Nik Hassan Suhaimi Nik Abd. Rahman and Zuliskandar Ramli (eds). Penanda Aras Penyelidikan Arkeologi Universiti Kebangsaan Malaysia, 12 13 Julai 2010, Bilik Senat \& Bilik Majlis, Canselori, Universiti Kebangsaan Malaysia, Bangi: Institut Islam dan Tamadun Melayu (ATMA). p.373-381.

Chia, S., Johan Arif and Matsumura, H., 2005. The dental characteristics of prehistoric human teeth from Melanta Tutup, Semporna, Sabah. In: Zuraina Majid (ed). Perak Man and other prehistoric skeletons in Malaysia. Pulau Pinang: Penerbit Universiti Sains Malaysia. p.239-251.

Cornwall, I.W., 1974 Bones for archaeologist. London: J.M. Dent \& Sons Ltd.

Cranbrook, Earl of, 1988. Report on bones from the Madai and Baturong Cave excavatios. Sabah Monograph 2. Sabah Museum and State Archives. p142-152.

Cranbrook, Earl of, 2010 Late quaternary turnover of mammals in Borneo: The zooarchaeological record. Biodivers Conservation, 19, p.373-391.

Dance, S.P., 1992. Shells. London: Dorling Kindersley.

Das, I., 2006. Snakes and other reptiles of Borneo. United Kingdom: New Holland Publishers (UK) Ltd.

Eng, K. K., 2009. Paleoanthropological study of late prehistoric human skeletal remains in Semporna, Sabah. Tesis MA, Universiti Sains Malaysia, Pulau Pinang.

Eng, K. K., and Chia, S. 2010. Pengkebumian zaman prasejarah akhir di Bukit Kamiri, Semporna, Sabah. Warisasn Arkeologi Malaysia, Series 3, p.44-58.

Faith, J.T., Dominguez-Rodrigo, M and Gordon, A.D., 2009. Long-distance carcass transport at Olduvai Gorge? A quantitative examation of bed 1 skeletal element abundances. Journal of Human Evolution, Vol. 56, p.247-256.

Femorale, 2017. THIARIDAE - Balanocochlis glandiformis (Schepman, 1896). [Online] Available at: http://www.femorale.com/shellphotos/detail.asp?url=\&species=Balanocochlis +glandiformis+(Schepman\%2C+1896)\&localidade=Malaysia [Accessed 6 Apr 2017]. 
Fiene-Severns, P., Severns, M. and Dyerly, R., 2004. Tropical seashells. Singapore: Periplus Editions (HK) Ltd.

Goh, H.M., 2010. Pengkebumian Pleistosen Akhir - Holosen Awal di Gua Kajang. Warisan Arkeologi Malaysia, Series 3, p.59-81.

Galli, C., 2016. WMSDB - Worldwide Mollusc Species Data Base. [Online] Available at: http://www.bagniliggia.it/WMSD/WMSDdownload.htm [Accessed 30 Oct 2016].

Giovas, C.M., 2009. The shell game: analytic problems in archaeological mollusc quantification. Journal of Archaeological Science, Vol. 36, p.1557-1564.

Grabarkiewz, D.J. and Davis, W.S., 2008. An introduction to freshwater fishers as biological indicators. Washington: United State Environmental Protection Agency.

Grant, J., Gorin, S. and Fleming, N., 2008. The archaeology coursebook: An introduction to themes, sites, methods and skills (Third edition). London: Routledge.

Harris, M., Weisler, M., and Faulkner, P., 2015. A refined protocol for calculating MNI in archaeological molluscan shell assemblages: a Marshall Island case study. Journal of Archaeological Science, Vol. 57, p.168-179.

Hesse, B. and Wapnish, P., 1985. Animal bone archaeologicalfrom objectives to analysis. Washington: Taraxacum Inc.

Hook, P., 2008. Seashells and the seashore. Bath: Parragon Books Ltd.

Koehler, F. and Glaubrecht, M., 2002. Annotated catalogue of the nominal taxa of Southeast Asian freshwater gastropods, family Pachychilidae Troschel, 1857 (Mollusca, Caenogastropoda, Cerithiodea), with an evaluation of the types. Zoosystematics and Evolution, Vol. 78(1), p.121-156.

Klein, R.G. and Cruz-Uribe, K., 1984. The analysis of animal bones from archaeological sites. London: The University of Chicago Press.

Leong, T.S. and Siow, K.T., 1984. Sea turtles in the East Coast of Peninsular Malaysia and their economic importance. In: Chua T.K. and Charles J.K. (eds). Coastal resources of East Coast Peninsular Malaysia. Pulau Pinang: Penerbit Universiti Sains Malaysia, p.192-207.

Lieske, E dan Myers, R., 1994. Reef Fishes of the world. Hong Kong: Periplus Editions (HK) Ltd.

Matsui, A., 2007. Fundamentals of zooarchaeology in Japan and East Asia. Japan: Kansai Process Limited.

Medway, L., 1959/60. Niah Shell - 1954-1958: A preliminary report. Sarawak Museum Journal, Vol. IX, Nos. 15-16 (New Series), p.368-379.

Medway, L., 1977. Mammals of Borneo. Monographs of the Malaysian Branch of the Royal Asiatic Society, No. 7.

Meehan, B., 1982. Shell Bed to Shell Midden. Canberra: Australian Institute of Aboriginal Studies.

Nilus, R., Chung, A.Y.C., Pereira, J.T., Sugau, J.B., Tangah, J., Sabran, S. and Chong, R.F.Y., 2010. Mangroves of Sabah An Introduction to the Flora and Fauna. Sandakan: Sabah Forestry Department.

Ono, R., 2004. Prehistoric fishing at Bukit Tengkorak, east coast of Borneo Island. New Zealand Journal of Archaeology, Vol. 24, p.77-106.

Ono, R., 2003. Prehistoric Austronesian fishing strategies: A comparison between Island Southeast Asia and the lapita cultural complex. In: Sand, C. (ed). Pacific archaeology: Assessments and prospects. Proceedings of the International Conference for the 50th Anniversary of the first Lapita Excavation. Kone-Noumea 2002. p.191-201.

Pickering, T.R and Egeland, C.P., 2006. Experimental patterns of hammerstone percussion damage on bones: Implications for inferences of carcass processing by humans. Journal of Acrhaeological Science, Vol. 33, p.459-469.

Pickering, T.R., Marean, C.W and Rodrigo, M.D., 2003. Importance of limb bone shaft fragments in zooarchaeology: A respons to "On in-situ attrion and vertebrate body part profiles 2002" by M.C. Stiner. Journal of Archaeological Science, Vol. 30, p.1469-1482.

Poppe, G.T. and Poppe, P., 2017. Shell Encyclopedia. [Online] Available at: Conchology,

Inc.http://www.conchology.be/?t=66\&family=THIARIDAE\&species=Balanocochlis\%20glandiformis [Accessed 6 Apr 2017].

Pookarjorn, S., 1994. Human activities and environmental change during the Late Pleistocene to Middle Holocene in Southern Thailand and Southeast Asia. Paper represented at S.A.A. Conference Anaheim, USA. 
Bujeng, V., \& Albert, D. D. A. (2017). Exploitation Of Aquatic Fauna During The Metal Age In Bukit Kamiri, Semporna, Sabah, Malaysia. Archives of Business Research, 5(5), 24-36.

Poutiers, J. M., 1998a. Bivalves (Acephala, Lamellibranchia, Pelecypoda). In: K. E. Carpenter, K.E. and Niem, V.H. (eds). FAO species identification guide for fishery purposes. The living marine resources of the Western Central Pacific. Volume 1. Seaweeds, corals, bivalves and gastropods. Rome: FA0. p. 123-352.

Poutiers, J. M., 1998b. Gastropods. In: K. E. Carpenter, K.E. and Niem, V.H. (eds). FAO species identification guide for fishery purposes. The living marine resources of the Western Central Pacific. Volume 1. Seaweeds, corals, bivalves and gastropods. Rome: FAO. p. 363-348.

Pyron, M. and Brown, K. M., 2015. Introduction to Mollusca and the Class Gastropoda. In: J. Thorp and D.C.Rogers (eds). Thorp and Covich's Freshwater Invertebrates: Ecology and General Biology (4th Ed). Oxford: Academic Press. p.383-421.

Reitz, E.J and Wing, E.S., 1999. Zooarchaeology. United Kingdom: Cambridge University Press.

Renfew, C and Bahn, P., 1996. Archaeology: Theories, Method and Practice (2nd edition). London: Thames and Hudson Ltd.

Ridzwan Hashim, 1993. Sumber makanan persisiran Laut Sabah. Kuala Lumpur: Dewan Bahasa dan Pustaka.

Saunders, G.D., 1979. Shells an introduction to seashells of the world. London: Usborne Publishing Limited.

Soejono, R.P., 2008. On Prehistoric Burial Method In Indonesia. Bulletin od the National Research Centre of Archaeology of Indonesia. Jakarta: Pusat Penelitian dan Pengembangan Arkeologi Nasional.p.1-40

Tsang, Cheng-hwa, 1992. Arcaheology of the P'eng-Hu Islands. (Special publication, No 95). Taiwan: Institute of History and Philology Academia Sinica.

Velat Bujeng and Chia, S., 2009. Zooarchaeological perspestives on faunal remains from Gua Kain Hitam B, Niah, Sarawak. Sarawak Museum Journal, Vol. LXVI (87 New Series), p.199-227.

Velat Bujeng and Chia, S., 2014. Sisa fauna vertebrata: Asosiasi dari bukti pengebumian prasejarah akhir di Bukit Kamiri dan Melanta Tutup, Semporna, Sabah. Monograf Muzium Sabah, Vol. 12, p.155-171.

Wong, T.M., Charles, J.K. and Khoo, T.K., 1984. The Mangrove Invertebrate Resources of the East Coast of Peninsular Malaysia. In: Chua T.E. and Charles, J.K. (eds). Coastal Resources of East Coast Peninsular Malaysia: An Assessment in Relation to Potential Oil Spills. Pulau Pinang: Penerbit Universiti Sains Malaysia. p. 110-130.

Yule, C.M. and Yong, H.S., 2004. Freshwater Invertebrata of the Malaysia Region. Kuala Lumpur: Monash University.

Zuraina Majid, 1994. The excavation of Perak Man, an Epi-Palaeolithic burial at Gua Gunung Runtuh. In: Zuraina Majid (ed). The excavation of Gua Gunung Runtuh and the discovery of the Perak Man in Malaysia. Kuala Lumpur: Department of Museums and Antiquity Malaysia.p.23-47.

Zuraina Majid, 2005. The excavation and analyses of the Perak Man buried in Gua Gunung Runtuh, Lenggong, Perak. In: Zuraina Majid (ed). The Perak Man and other prehistoric skeletons of Malaysia. Pulau Pinang: Penerbit Universiti Sains Mala 